like charged particles in the synthetic electric field that was induced by changing the electromagnetic vector potential.

Nature Phys. doi:10.1038/

nphys1954 (2011)

\section{PLANETARY SCIENCE}

\section{Methane rain} falls on Titan

Images from NASA's Cassini probe revealed vast lakes of liquid hydrocarbons around the poles of Titan,

Saturn's largest moon, in

2006. Elizabeth Turtle of

Johns Hopkins

University's

Applied Physics

Laboratory in

Laurel, Maryland,

and her colleagues now

add the discovery that

methane probably rains

on Titan at low equatorial latitudes.

Images of the arid equatorial region taken by Cassini last October show dunes that appear darker after clouds had passed overhead. This suggests that the clouds rained liquid methane, which wet the surface, says the team. Such rain is thought to be seasonal and may play a part in dune formation by cementing fine atmospheric aerosol particles.

Science 331, 1414-1417 (2011)

\section{CHEMISTRY}

\section{Copper makes for selectivity}

Carbon-based compounds attached to a lithium atom are widely used in chemical reactions to add new carbon-carbon bonds to molecules. However, these organolithium reagents are not normally selective enough to create only one of two possible mirror-image forms, or enantiomers, of the same molecule.

Ben Feringa, Syuzanna Harutyunyan and their colleagues at the University of Groningen in the Netherlands now show off a way to use these organolithium reagents in a highly selective manner. Using these reagents, the team demonstrated selectivity of $90 \%$ or higher for one enantiomer in more than 20 different reactions.

Nature Chem. doi:10.1038/ nchem.1009 (2011)

\section{DEVELOPMENT}

\section{How the chicken's neck got naked}

How chickens of a particular breed ensure that their necks

remain feather free an adaptation to hot weather - has been explained.

Denis Headon at the University of Edinburgh, UK, and his co-workers found that naked neck chickens (pictured) have a

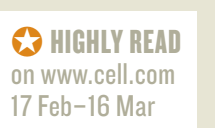
Cell 144, 796-809 (2011) mutation that boosts levels of the protein BMP12. Adding this protein to neck skin tissue cultures from normal chickens blocked feather formation, although the treatment had little effect on skin cultures from other parts of the body. The skin on chickens' necks naturally contains high levels of a signalling molecule called retinoic acid. This, the researchers show, primes neck skin cells to respond to the extra BMP12 made by naked neck chickens, preventing feather growth.

PLoS Biol. 9, e1001028 (2011)

\section{CLIMATE MODELLING}

\section{Melting of the third pole}

Aerosols such as black carbon and dust particles seem to have a greater effect on the Tibetan Plateau's snow than does anthropogenic climate change. Yun Qian of the Pacific

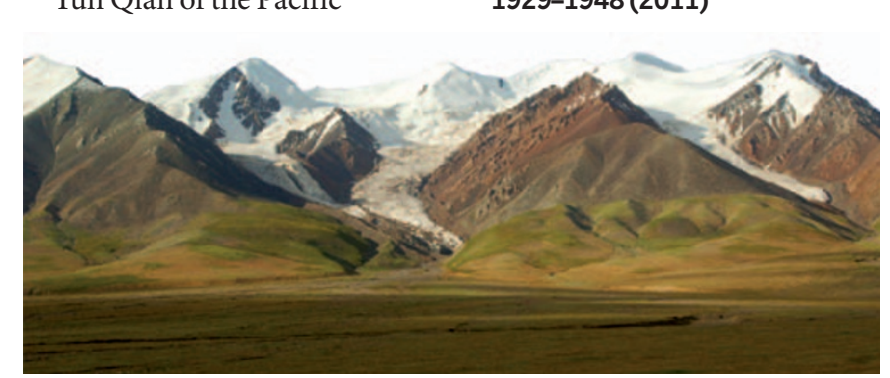

Northwest National Laboratory in Richland, Washington, and his colleagues simulated the impact of carbon dioxide and aerosols on the snowpack using a global climate model. They found that the deposition of black carbon on snow increases the surface air temperature by an average of $1^{\circ} \mathrm{C}$ across the plateau because it boosts the absorption of sunlight. From April to July, black carbon is up to four times more effective at melting snowpack per degree of warming it induces than is air warming from increased atmospheric carbon dioxide.

Aerosols have a larger effect on the Tibetan Plateau (pictured) than on any other snow-covered region in the world, producing earlier snowmelt and affecting monsoon trends, the authors report.

Atmos. Chem. Phys. 11, 1929-1948 (2011)
The most viewed papers in science

\title{
Skeleton boosts stud quotient
}

That gonadal hormones influence bone remodelling has been well documented, but it is not the end of the story. Gerard Karsenty at Columbia University in New York and his colleagues have found that this influence runs in both directions - although only in males.

They show that the hormone osteocalcin, made by bone cells called osteoblasts, induces testosterone production by testicular Leydig cells, the body's key testosterone factories. The researchers demonstrate this in both mouse-cell cultures and live mice, and also identify an osteocalcin receptor expressed in Leydig cells but not in follicular cells of the ovary. Male mice engineered to lack this receptor are subfertile, as are male mice engineered to lack osteocalcin.

\section{MICROBIOLOGY}

\section{Sugary coat of armour}

The soil-dwelling bacterium Bacillus cereus is a close relative of the microbe responsible for anthrax, and can cause a similar illness if it is inhaled by people with damaged lungs.

Olaf Schneewind and his co-workers at the University of Chicago in Illinois find that a pathogenic strain of B. cereus harbours two sets of genes that encode protective sugar coats. These coats prevent the bacteria from being engulfed and destroyed by certain immune cells. One gene set produces a protective capsule made of the sugar hyaluronic acid, whereas the other capsule is made of an unidentified sugar.

Knocking out one set of the capsule-making genes reduced the microbe's virulence in mice; if both were knocked out, the bacteria no longer caused disease. Mol. Microbiol. doi:10.1111/ j.1365-2958.2011.07582.x (2011)

\section{$\rightarrow$ NATURE.COM}

For the latest research published by Naturevisit:

www.nature.com/latestresearch 